International Journal of Engineering \& Technology, $7(2.27)(2018) 295-299$
International Journal of Engineering \& Technology
SPC
Website: www.sciencepubco.com/index.php/IJET
Research paper

\title{
Application program learning based on android for students experiences
}

\author{
Nur Aminudin ${ }^{1}$, Fauzi ${ }^{1}$, Miftachul Huda ${ }^{2}$, Aminudin Hehsan ${ }^{3}$, Mohd. Nasir Ripin ${ }^{3}$, Zulkifli Haron ${ }^{3}$, \\ Juhazren Junaidi ${ }^{3}$, Rita Irviani ${ }^{1}$, Muhamad Muslihudin ${ }^{1}$, Syahromi Hidayat ${ }^{1}$, \\ Andino Maseleno ${ }^{1,4^{*}}$, Miswan Gumanti ${ }^{1}$, Almira Nabila Fauzi ${ }^{5}$ \\ ${ }^{1}$ STMIK Pringsewu, Lampung, Indonesia \\ ${ }^{2}$ Faculty of Social Sciences and Humanities, Universiti Teknologi Malaysia, Malaysia \\ ${ }^{3}$ Centre of Research for Fiqh Science and Technology (CFIRST), Universiti Teknologi Malaysia, Malaysia \\ ${ }^{4}$ Institute of Informatics and Computing Energy, Universiti Tenaga Nasional, Malaysia \\ ${ }^{5}$ Monash University, Malaysia \\ *Corresponding author E-mail: andimaseleno@gmail.com
}

\begin{abstract}
With the advancement of the era that increasingly rapidly affect the pattern of all-dependent life with advanced technology that allows us to do many things in everyday life in accordance with our needs such as using gadgets as a medium of learning. By using Android based gadgets we can use it to learn to play guitar that is supported by the Android application program that presents learning about playing guitar. Using gadgets as a medium of learning is an interesting and very easy. Android application program about learning to play the guitar is facilitate us in learning. Gadget as a medium of learning is an utilization technological developments that are worth positive and useful for us. Android guitar application presents about the correct guitar playing procedure and there chord and chord sound, not only see the chord form but we can listen to chords. Application made using prototyping method so that will continue to be fixed when there are deficiencies. This application will continue to grow in accordance with the needs of the user. This application is made to facilitate the learning process. Application users will continue to be developed to fit the needs of users and become the right facilities and useful for its users.
\end{abstract}

Keywords: Learning; Application; Gadget; Android; Student.

\section{Introduction}

\subsection{Background}

The rapid development of technology today is very easy for us as users to be able to access it according to our needs [1-3]. Just by using gadgets that we have we can do many things such as using gadgets to exchange news with friends, family, relatives even we can use our gadgets as a learning medium [4-6]. In this modern era the majority of Indonesia's population has been using gadgets as a very important facility to help finish the work done.gadgetpun is an important requirement because it has become the demands of people's lifestyle at this time [7-9].

In the software industry, gadgets refer to computer programs that provide services without the need for an independent app to be launched separately, but instead run in an environment that manages multiple gadgets [10-12]. There are several implementations based on existing software development techniques, such as JavaScript, input form and various formats picture [13-15]. Some examples of such software are Google Gadgets, Microsoft Gadgets, google desktop and Apple Widgets Dashboard software [16-18]. In the current era of many features Android-based gadget applications that can be created as a learning medium for users such as learning applications Android based guitar.

\subsection{Problem formulation}

How to design and build an Android guitar based learning program?

\subsection{Objective}

1) Creating applications to simplify the process of learning to play the guitar.

2) Learn creatively and innovatively by creating and developing application programs.

3) With the creation of Android guitar-based learning applications then the process of learning to play the guitar will be easier

\section{Theoretical}

\subsection{Application}

Understanding the application is a program that people use to do something on a computer system [19-21]. Mobile can be interpreted as an easy transfer from one place to another, for example a mobile phone means that a telephone terminal that can move easily from one place to another without disconnection or disconnection of communication [22-24]. Mobile app systems are 
applications that can be used even if the user moves easily from one place to another without the interruption or disconnection of communication. This app can be accessed via wireless devices such as pagers, such as cell phones and PDAs.

\subsection{Android}

Mobile application programming of smartphones and tablet PC based on Android is an operating system on mobile which is open and based on Linux operating system [25-27]. Android can be used by anyone who wants to use it on their device. Android provides an open platform for developers to create their own applications that will be used for a variety of mobile devices. Initially, Google Inc. buy Android Inc., a newcomer who makes software for mobile phones. Then to develop Android, the Open Handset Alliance was formed, a consortium of 34 hardware, software and telecommunications companies, including Google, HTC, Intel, Motorola, Qualcomm, TMobile and Nvidia. At the inaugural release of Android, November 5, 2007, 10 Android alongside the Open Handset Alliance stated it supports the development of open standards on mobile devices. On the other hand, Google released Android codes under the Apache license, a software license and an open standard mobile device.

1) Methods

2) The process of building this program using prototyping method is the application program will continue to be tested and carried out an update to improve the effectiveness of the application as a medium of learning:

3) Design program. Designing the program to be built.This stage is the earliest stage.perancanagn required for the process can run according to procedures that have been designed.

4) Design. At this stage the program to be made done this designing stage is the second stage after designing. this is the start of program development process until become the desired application.

5) Testing. Conducted testing after the application program is built and implemented to test whether this application has been successfully built properly.

6) Implementation. After the application program pass the testing phase it is time to implement it and evaluate in order to know the deficiencies in this application.

Figure 1 shows scheme of application program development process:

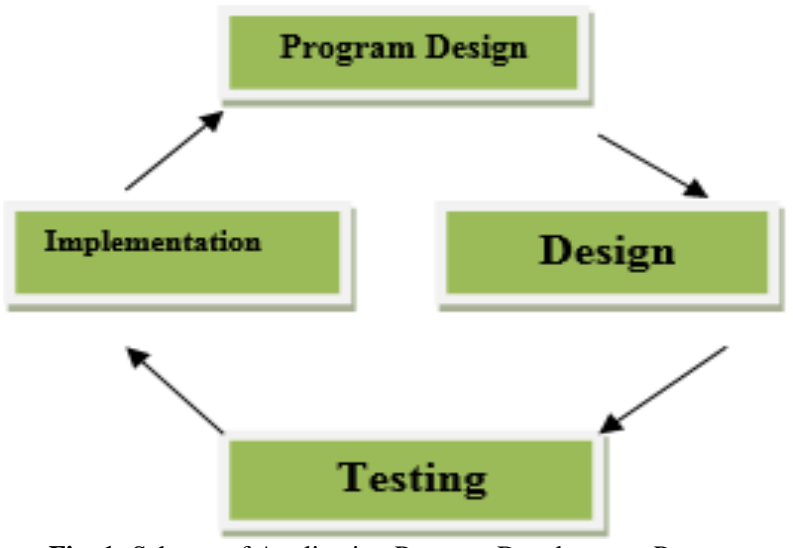

Fig. 1: Scheme of Application Program Development Process.

\section{Results}

Development of Android based application program can be done by using MIT appinventor, this software provides features to build an Android based applications that we also can sell through google playstrore. Many applications model that can be made in mit appinvertor like game applications, social media. The author conducted an experiment to build an application based on Android guitar learning, which contains about tutorial how to learn guitar in the hope this application can be a reference as an interesting learning media. Here is a step-making application learn based on guitar Android using mit app invertor.

1) Sign in to MIT App Inventor

The first step is we have to go into mit appinvertor by:

- $\quad$ open the browser according to taste, eg google chrome.

- Call MIT appinvertor by typing "MITappinventor" in the URL field to go to

- Make sure the computer has an Internet connection.

- Once inside the MIT appinventor page click CREAT APPS Figure 2 shows MIT App Inventor.

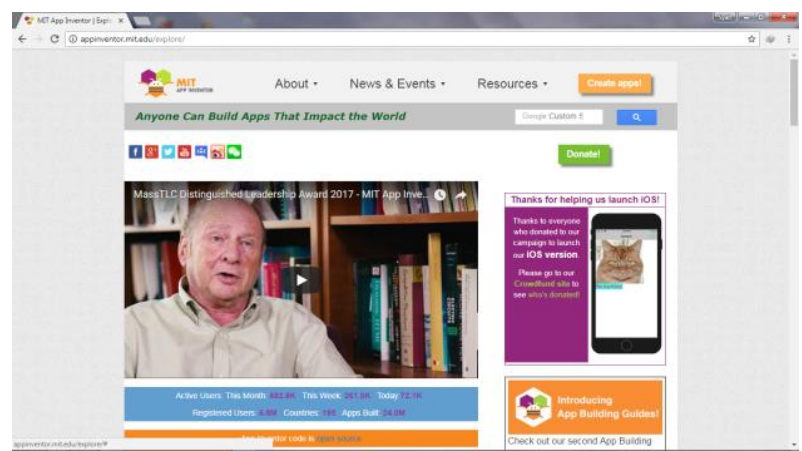

Fig. 2: MIT App Inventor

After click creat apps it will go to the following page:

Here is the description of the image above:

1) Start New Project: To create a new application project

2) Delete: To delete the application project that has been created

3) My Project: Contains a list of project names, cure project date created and project date modified

2) Aplication Design

Before doing the machining then we must know in advance the function of the existing components in the appinvertor. After know the components that are in the appinvertor then we click the new project and give the name of the application to be made as shown in Figure 3.

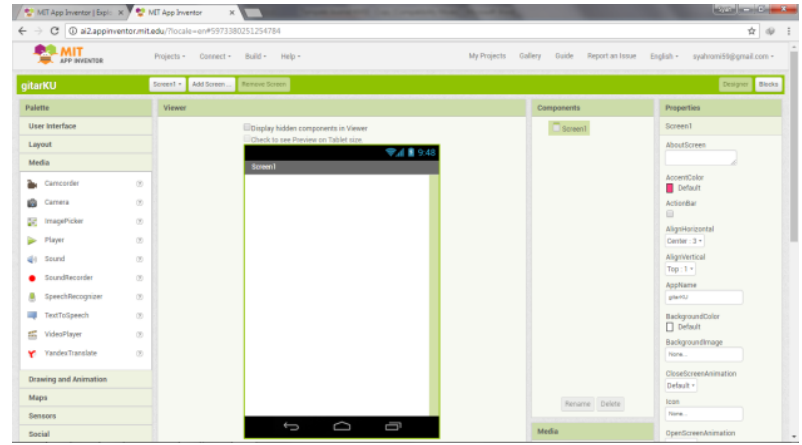

Fig. 3: New Project.

At design stage, we can use PALETTE which is on the left side of the screen to do design. At inside there are PALETTE user Interface, Media, Layout, Drawing and Animation, Maps, Sensors, Social, Conectivity. Use as needed. in the middle of the screen there is VIEW to see the process being done, right side there is PROPERTIS to set the display as shown in Figure 4.

- Viewer Column: Works to display / locate the selected component. All that is in this viewer section that will be visible when the project is run

- Components Column: Contains a list of all the components we use / insert in the project / viewer. When we add a component to the viewer / project, then the table of contents

- Components will increase according to the type of component that is inserted 
- Media Column: Contains a list of media (images, clip art, sound, music, or movie) that we insert into the project

- Properties Column: Works to set the properties of the components we use.

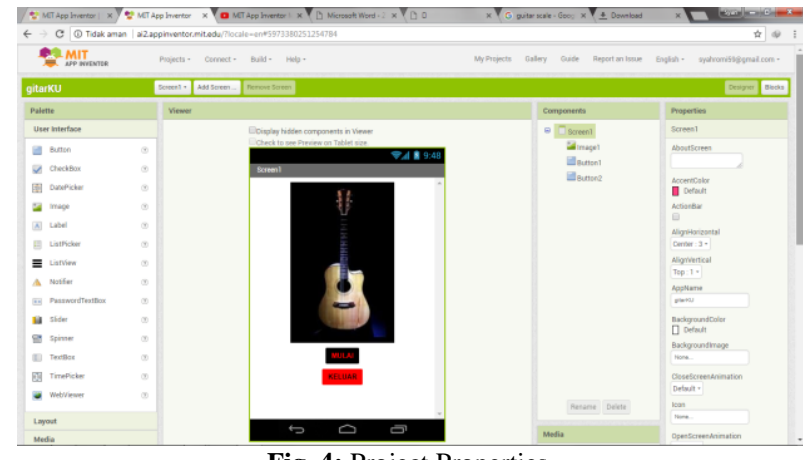

Fig. 4: Project Properties

After the application has been completed at the next design stage set the command of the components that exist in the application by clicking the block icon on the top right corner of the screen then set according to the needs as shown in Figure 5.

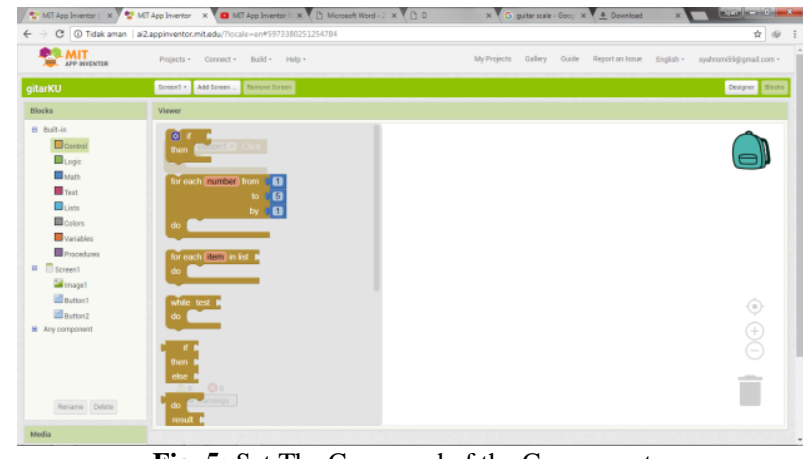

Fig. 5: Set The Command of the Components.

The last process after the previous steps are done next we make the application we have created into an Android app or apk. Go to the build menu and select the app (save to my computer) as shown in Figure 6.

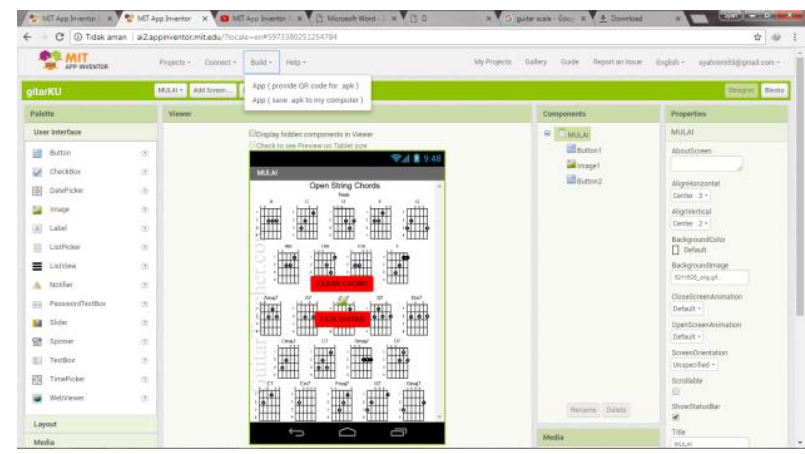

Fig. 6: Apkdownloading.

After successfully downloaded apk file transfer to Android we then install and use the application. Learning application through notebook for instance could be determined with the particular trends to give insights into considering the adoption of technological devices [28-30]. Widely adopted to help access to the interactions amidst the human daily life [31-33], the wide range of benefit could be transmitted into learning, business, communication and other tasks [34] [35] [36]. Developed with the distinctive features, giving facilitation on the Android basis mode could be facilitated more simply through the basis of one touch screen [37-40]. This initiative should do with encouraging the entire basis in enabling them freely to expand the users' creativity [41-44]. Through this initiative, the emerging trends to commit with measurement in maximizing Android-based learning model should bring along with enlarging the skills linked into the personalized behavior [4547]. Moreover, the number of subject expertise points out considering the necessity to elaborate the way in managing the featured contribution to run the learning analytic [48-50]. In terms of enlarging the initiative to strengthen the initial value of expanding the way in the selection process, attempts to enhance the innovative approach in determining the quality assurance of this model basis should bring along with achieving the wide interaction to incorporate the analytical process together with the appropriate means [51-53]. With this initiative [54-56], the way to have good appointment in achieving the core point of value in underlying the interaction along with interactive and innovative basis [57-58] refers to expand the attempts to deliver the strategic initiative of application through Android based learning approach. Incorporate into the wide range of approaches with the particular attention, the valuable contribution in obtaining the basic involvement through expanding the process itself should do with procedural context to achieve a significant attribution enhanced in line with gaining the core component in an insightful performance into achieving the good appointment. As a result, the learning application with such approach initiative would have a significant role in delivering the transfer basis into achieving the good result

\section{Conclusion}

This Android guitar-based learning application is very easy for us in learning to play the guitar because we can do it yourself by following the guidelines that exist in the guitar learning tutorial in this application. This application is only as a basic reference of learning that is basic to become more experts needed latian routine and diligent search for the latest references.

\section{Acknowledgement}

This study was part of a research conducted under sponsorship of the Universiti Teknologi Malaysia (Q.J130000.2533.19H96) related to the Research Development Miswak Sugi Design.

\section{References}

[1] Bob susanto, 14 juni 2016, pengertian aplikasi menurut para ahli, http://www.spengetahuan.com/2016/06/10-pengertian-aplikasimenurut-para-ahli-lengkap.html

[2] Nasrudin safaat, program aplikasi mobile smartphone dan PC berbasis android, 2012

[3] Rizal loa wanda,12 januari 2018,pengertian prototyping model, http://rizalloa.ilearning.me/?p=132

[4] Sariyun Naja Anwar, Isworo Nugroho dan Endang Lestariningsih,2015, Perancangan dan Implementasi Aplikasi Mobile Semarang Guidance Pada Android

[5] Aditia novit, 2015,pengertian MITappinventor, http://novitstudio.blogspot.com/2015/10/pengertian-mit-appinventor-2.html

[6] Adela, A., Jasmi, K.A., Basiron, B., Huda, M., Maseleno, A. (2018) Selection of dancer member using simple additive weighting. International Journal of Engineering \& Technology. 7(3). 1096-1107. https://doi.org/10.14419/ijet.v7i3.11983.

[7] Aminin, S., Huda, M., Ninsiana, W., and Dacholfany, M.I. (2018). Sustaining civic-based moral values: Insights from language learning and literature. International Journal of Civil Engineering and Technology. 9(4), 157-174.

[8] Amin, M.M., Nugratama, M.A.A., Maseleno, A., Huda, M., Jasmi, K.A., (2018). Design of cigarette disposal blower and automatic freshner using mq-5 sensor based on atmega 8535 microcontroller. International Journal of Engineering \& Technology. 7(3). 11081113. https://doi.org/10.14419/ijet.v7i3.11917.

[9] Atmotiyoso, P. and Huda, M. (2018). Investigating Factors Influencing Work Performance on Mathematics Teaching: A Case Study. International Journal of Instruction. 11(3), 391-402. https://doi.org/10.12973/iji.2018.11327a.

[10] Huda, M., \& Teh, K. S. M. (2018). Empowering Professional and Ethical Competence on Reflective Teaching Practice in Digital Era. In Dikilitas, K., Mede, E., Atay D. (Eds). Mentorship Strategies in 
Teacher Education (pp. 136-152). Hershey, PA: IGI Global. https://doi.org/10.4018/978-1-5225-4050-2.ch007.

[11] Huda, M., Teh, K.S.M., Nor, N.H.M., and nor, M.B.M. (2018a) Transmitting Leadership Based Civic Responsibility: Insights from Service Learning. International Journal of Ethics and Systems, 34(1), 20-31. https://doi.org/10.1108/IJOES-05-2017-0079.

[12] Huda, M., Maseleno, A., Muhamad, N.H.N., Jasmi, K.A., Ahmad, A., Mustari, M.I., Basiron, B. (2018b). Big Data Emerging Technology: Insights into Innovative Environment for Online Learning Resources. International Journal of Emerging Technologies in Learning 13(1), 23-36. https://doi.org/10.3991/ijet.v13i01.6990.

[13] Huda, M., Maseleno, A., Teh, K.S.M., Don, A.G., Basiron, B. Jasmi, K.A., Mustari, M.I., Nasir, B.M., and Ahmad, R. (2018c). Understanding Modern Learning Environment (MLE) in Big Data Era. International Journal of Emerging Technologies in Learning. 13(5), 71-85. https://doi.org/10.3991/ijet.v13i05.8042.

[14] Huda, M. (2018b). Empowering Application Strategy in the Technology Adoption: Insights from Professional and Ethical Engagement. Journal of Science and Technology Policy Management. doi.org/10.1108/JSTPM-09-2017-0044

[15] Huda. M. \& Sabani, N. (2018). Empowering Muslim Children's Spirituality in Malay Archipelago: Integration between National Philosophical Foundations and Tawakkul (Trust in God). International Journal of Children's Spirituality, 23(1), 81-94. https://doi.org/10.1080/1364436X.2018.1431613.

[16] Huda, M., Qodriah, S.L., Rismayadi, B., Hananto, A., Kardiyati, E.N., Ruskam, A., and Nasir, B.M. (2018). Towards Cooperative with Competitive Alliance: Insights into Performance Value in Social Entrepreneurship in Creating Business Value and Competitive Advantage with Social Entrepreneurship. (pp.294). Hershey, PA: IGI Global.

[17] Huda, M., Hehsan, A., Basuki, S., Rismayadi, B., Jasmi, K. A., Basiron, B., \& Mustari, M. I. (2019). Empowering Technology Use to Promote Virtual Violence Prevention in Higher Education Context. In Intimacy and Developing Personal Relationships in the Virtual World (pp. 272-291). Hershey, PA: IGI Global. https://doi.org/10.4018/978-1-5225-4047-2.ch015.

[18] Huda, M., Ulfatmi, Luthfi, M.J., Jasmi, K.A., Basiron, B., Mustari, M.I., Safar, A., Embong, H.W.H., Mohamad, A.M., and Mohamed, A.K. (2019). Adaptive online learning technology: Trends in big data era in Diverse Learning Opportunities Through TechnologyBased Curriculum Design. Hershey, PA: IGI Global. (In press).

[19] Kurniasih, D., Jasmi, K.A., Basiron, B., Huda, M., Maseleno, A. (2018). The uses of fuzzy logic method for finding agriculture and livestock value of potential village. International Journal of Engi$\begin{array}{llll}\text { neering } \quad \& \quad \text { Technology. } & \text { 7(3). 1091-1095. }\end{array}$ https://doi.org/10.14419/ijet.v7i3.11984.

[20] Maseleno, A., Pardimin, Huda, M., Ramlan, Hehsan, A., Yusof, Y.M., Haron, Z., Ripin, M.N., nor, N.H.M., and Junaidi, J. (2018a). Mathematical Theory of Evidence to Subject Expertise Diagnostic. ICIC Express Letters, 12 (4), 369 DOI: 10.24507/icicel.12.04.369

[21] Maseleno, A., Huda, M., Jasmi, K.A., Basiron, B., Mustari, I., Don, A.G., and Ahmad, R. (2018b). Hau-Kashyap approach for student's level of expertise. Egyptian Informatics Journal, https://doi.org/10.1016/j.eij.2018.04.001 ...

[22] Maseleno, A., Sabani, N., Huda, M., Ahmad, R., Jasmi, K.A., Basiron, B. (2018c). Demystifying Learning Analytics in Personalised Learning. International Journal of Engineering \& Technology. 7(3). 1124-1129. https://doi.org/10.14419/ijet.v7i3.9789.

[23] Moksin, A. I., Shahrill, M., Anshari, M., Huda, M., \& Tengah, K. A (2018b). The Learning of Integration in Calculus Using the Autograph Technology. Advanced Science Letters, 24(1), 550-552. https://doi.org/10.1166/asl.2018.12067.

[24] Putra, D.A.D., Jasmi, K.A., Basiron, B., Huda, M., Maseleno, A., Shankar, K., Aminudin, N. (2018). Tactical Steps for EGovernment Development. International Journal of Pure and Applied Mathematics. 119 (15). 2251-2258.

[25] Rosli, M.R.B., Salamon, H.B., and Huda, M. (2018). Distribution Management of Zakat Fund: Recommended Proposal for Asnaf Riqab in Malaysia. International Journal of Civil Engineering and Technology 9(3), pp. 56-64.

[26] Sugiyarti, E., Jasmi, K.A., Basiron, B., Huda, M., Shankar, K., Maseleno, A. (2018). Decision support system of scholarship grantee selection using data mining. International Journal of Pure and Applied Mathematics. 119 (15), 2239-2249.

[27] Sundari, E., Jasmi, K.A., Basiron, B., Huda, M., and Maseleno, A (2018). Web-Based Decision Making System for Assessment of Employee Revenue using Weighted Product. International Journal of Engineering and Technology.
[28] Susilowati, T., Jasmi, K.A., Basiron, B., Huda, M., Shankar, K., Maseleno, A., Julia, A., Sucipto. (2018). Determination of Scholarship Recipients Using Simple Additive Weighting Method. International Journal of Pure and Applied Mathematics. 119 (15), 22312238.

[29] Anshari, M., Almunawar, M. N., Shahrill, M., Wicaksono, D. K., \& Huda, M. (2017). Smartphones usage in the classrooms: Learning aid or interference. Education and Information Technologies, 22(6), 3063-3079. https://doi.org/10.1007/s10639-017-9572-7.

[30] Huda, M., Sabani, N., Shahrill, M., Jasmi, K. A., Basiron, B., \& Mustari, M. I. (2017a). Empowering Learning Culture as Student Identity Construction in Higher Education. In A. Shahriar, \& G. Syed (Eds.), Student Culture and Identity in Higher Education (pp. 160-179). Hershey, PA: IGI Global. https://doi.org/10.4018/978-15225-2551-6.ch010.

[31] Huda, M., Jasmi, K. A., Hehsan, A., Shahrill, M., Mustari, M. I., Basiron, B., \& Gassama, S. K. (2017b). Empowering Children with Adaptive Technology Skills: Careful Engagement in the Digital Information Age. International Electronic Journal of Elementary Education, 9(3), 693-708.

[32] Huda, M., Shahrill, M., Maseleno, A., Jasmi, K. A., Mustari, I., \& and Basiron, B. (2017c). Exploring Adaptive Teaching Competencies in Big Data Era. International Journal of Emerging Technologies in Learning, 12(3), 68-83. https://doi.org/10.3991/ijet.v12i03.6434.

[33] Huda, M., Jasmi, K. A., Basiran, B., Mustari, M. I. B., \& Sabani, A. N. (2017d). Traditional Wisdom on Sustainable Learning: An Insightful View From Al-Zarnuji's Ta 'lim al-Muta 'allim. SAGE Open, 7(1), 1-8. https://doi.org/10.1177/2158244017697160.

[34] Huda, M., Jasmi, K. A., Embong, W. H., Safar, J., Mohamad, A. M., Mohamed, A. K., Muhamad, N. H., Alas, Y., \& Rahman, S. K. (2017e). Nurturing Compassion-Based Empathy: Innovative Approach in Higher Education. In M. Badea, \& M. Suditu (Eds.), Violence Prevention and Safety Promotion in Higher Education Settings (pp. 154-173). Hershey, PA: IGI Global. https://doi.org/10.4018/978-1-5225-2960-6.ch009.

[35] Huda, M., Jasmi, K. A., Alas, Y., Qodriah, S. L., Dacholfany, M. I., \& Jamsari, E. A. (2017f). Empowering Civic Responsibility: Insights From Service Learning. In S. Burton (Ed.), Engaged Scholarship and Civic Responsibility in Higher Education(pp. 144165). Hershey, PA: IGI Global. https://doi.org/10.4018/978-1-52253649-9.ch007.

[36] Huda, M., Jasmi, K. A., Mustari, M. I., Basiron, B., Mohamed, A. K., Embong, W., ... \& Safar, J. (2017g). Innovative E-Therapy Service in Higher Education: Mobile Application Design International Journal of Interactive Mobile Technologies, 11(4), 83-94. https://doi.org/10.3991/ijim.v11i4.6734.

[37] Huda, M., Jasmi, K. A., Mustari, M. I., \& Basiron, B. (2017h). Understanding Divine Pedagogy in Teacher Education: Insights from Al-zarnuji's Ta'lim Al-Muta'Allim. The Social Sciences, 12(4), 674-679.

[38] Huda, M., Jasmi, K. A., Mustari, M. I. B., \& Basiron, A. B. (2017i). Understanding of Wara' (Godliness) as a Feature of Character and Religious Education. The Social Sciences, 12(6), 1106-1111.

[39] Huda, M., Siregar, M., Ramlan, Rahman, S.K.A., Mat Teh, K.S., Said, H., Jamsari, E.A., Yacub, J., Dacholfany, M.I., \& Ninsiana, W. (2017j). From Live Interaction to Virtual Interaction: An Exposure on the Moral Engagement in the Digital Era. Journal of Theoretical and Applied Information Technology, 95(19), 49644972.

[40] Huda, M., Maseleno, A., Jasmi, K. A., Mustari, I., \& Basiron, B. (2017k). Strengthening Interaction from Direct to Virtual Basis: Insights from Ethical and Professional Empowerment. International Journal of Applied Engineering Research, 12(17), 6901-6909.

[41] Huda, M., Haron, Z., Ripin, M. N., Hehsan, A., \& Yaacob, A. B. C. (20171). Exploring Innovative Learning Environment (ILE): Big Data Era. International Journal of Applied Engineering Research, 12(17), 6678-6685.

[42] Maseleno, A., Huda, M., Siregar, M., Ahmad, R., Hehsan, A., Haron, Z., Ripin, M.N., Ihwani, S.S., and Jasmi, K.A. (2017). Combining the Previous Measure of Evidence to Educational Entrance Examination. Journal of Artificial Intelligence 10(3), 8590. https://doi.org/10.3923/jai.2017.85.90.

[43] Huda, M., Anshari, M., Almunawar, M. N., Shahrill, M., Tan, A., Jaidin, J. H., \& Masri, M. (2016a). Innovative Teaching in Higher Education: The Big Data Approach. The Turkish Online Journal of Educational Technology, 15(Special issue), 1210-1216.

[44] Huda, M., Yusuf, J. B., Jasmi, K. A., \& Nasir, G. A. (2016b). Understanding Comprehensive Learning Requirements in the Light of 
al-Zarnūjī’s Ta‘līm al-Muta‘allim. Sage Open, 6(4), 1-14. https://doi.org/10.1177/2158244016670197.

[45] Huda, M., Yusuf, J. B., Jasmi, K. A., \& Zakaria, G. N. (2016c). AlZarnūjī's Concept of Knowledge ('ilm). SAGE Open, 6(3), 1-13. https://doi.org/10.1177/2158244016666885.

[46] Huda, M., Jasmi, K. A., Mohamed, A. K., Wan Embong, W. H., \& and Safar, J. (2016d). Philosophical Investigation of Al-Zarnuji's Ta'lim al-Muta'allim: Strengthening Ethical Engagement into Teaching and Learning. Social Science, 11(22), 5516-551.

[47] Kartanegara, M., \& Huda, M. (2016). Constructing Civil Society: An Islamic Cultural Perspective. Mediterranean Journal of Social Science, 7(1), 126-135

[48] Othman, R., Shahrill, M., Mundia, L., Tan, A., \& Huda, M. (2016). Investigating the Relationship between the Student's Ability and Learning Preferences: Evidence from Year 7 Mathematics Students. The New Educational Review, 44(2), 125-138.

[49] Wulandari, Aminin, S., Dacholfany, M.I., Mujib, A., Huda, M., Nasir, B.M., Maseleno, A., Sundari, E., Fauzi, Masrur, M., Design of Library Information Systems. International Journal of Engineering and Technology (UAE) (In Press).

[50] Susilowati, T., Teh, K.S.T., Nasir, B.M., Don, A.G., Huda, M., Hensafitri, T., Maseleno, A., Oktafianto, Irawan, D. Learning Application of Lampung Language Based on Multimedia Software. International Journal of Engineering and Technology (UAE) (In Press).

[51] Abadi, S., Teh, K.S.M., Nasir, B.M., Huda, M., Ivanova, N.L., Sari, T.I., Maseleno, A., Satria, F., Muslihudin, M. Application Model of K-Means Clustering Insights into Promotion Strategy of Vocational High School. International Journal of Engineering and Technology (UAE) (In Press).

[52] Susilowati, T., Dacholfany, M.I., Aminin, S., Ikhwan, A., Nasir, B.M., Huda, M., Prasetyo, A., Maseleno, A., Satria, F., Hartati, S., Wulandari. Getting Parents Involved in Child's School: Using Attendance Application System Based on SMS Gateway. International Journal of Engineering and Technology (UAE) (In Press).

[53] Aminudin, N., Huda, M., Ihwani, S.S., Noor, S.S.M., Basiron, B., Jasmi, K.A., Safar, J., Mohamed, A.K., Embong, W.H.W., Mohamad, A.M., Maseleno, A., Masrur, M., Trisnawati, Rohmadi, D. The Family Hope Program using AHP Method. International Journal of Engineering and Technology (UAE) (In Press).

[54] Abadi, S., Teh, K.S.M., Huda, M., Hehsan, A., Ripin, M.N., Haron, Z., Muhamad, N.H.N., Rianto, R., Maseleno, A., Renaldo, R., Syarifudin, A. Design of student score application for assessing the most outstanding student at vocational high school. International Journal of Engineering and Technology (UAE) (In Press).

[55] Aminudin, N., Huda, M., Kilani, A., Embong, W.H.W., Mohamed, A.M., Basiron, B., Ihwani, S.S., Noor, S.S.M., Jasmi, K.A., Safar, J., Ivanova, N.L., Maseleno, A., Triono, A., Nungsiati. Higher Education Selection using Simple Additive Weighting. International Journal of Engineering and Technology (UAE) (In Press).

[56] Anggraeni, E.Y., Huda, M., Maseleno, A., Safar, J., Jasmi, K.A., Mohamed, A.K., Hehsan, A., Basiron, B., Ihwani, S.S., Embong, W.H.W., Mohamad, A.M., Noor, S.S.M., Fauzi, A., Wijaya, D.A., Masrur, M. Poverty Level Grouping using SAW Method. International Journal of Engineering and Technology (UAE) (In Press).

[57] Abadi, S., Huda, M., Jasmi, K.A., Noor, S.S.M., Safar, J., Mohamed, A.K., Embong, W.H.W., Mohamad, A.M., Hehsan, A., Basiron, B., Ihwani, S.S., Maseleno A., Muslihudin, M., Satria, F., Irawan, D., Hartati, S. Determination of the Best Quail Eggs using Simple Additive Weighting. International Journal of Engineering and Technology (UAE) (In Press).

[58] Abadi, S., Huda, M., Hehsan, A., Mohamad, A.M., Basiron, B., Ihwani, S.S., Jasmi, K.A., Safar, J., Mohamed, A.K., Embong, W.H.W., Noor, S.S.M., Brahmono, B., Maseleno, A., Fauzi, A., Aminudin, N., Gumanti, M. Design of online transaction model on traditional industry in order to increase turnover and benefits. Inter national Journal of Engineering and Technology (UAE) (In Press).

[59] Abadi, S., Huda, M., Basiron, B., Ihwani, S.S., Jasmi, K.A., Hehsan, A., Safar, J., Mohamed, A.K., Embong, W.H.W., Mohamad, A.M., Noor, S.S.M., Novita, D., Maseleno, A., Irviani, R., Idris, M. Muslihudin, M. Implementation of Fuzzy Analytical Hierarchy Process on Notebook Selection. International Journal of Engineering and Technology (UAE) (In Press). 